\title{
Introduction to the Open File
}

\author{
Faryal Khan · Olav Christensen
}

Published online: 21 October 2009

(C) UNESCO IBE 2009

This special issue of Prospects provides a synopsis of global and regional trends in aid effectiveness in education to strengthen efforts for the implementation of the Paris Declaration and the Accra Agenda for Action. The articles undertake an in-depth analysis of the emerging aid environment and fiscal architecture at global and country levels, while exploring the gaps and setting priorities to accelerate financing of the Education for All (EFA) initiative, particularly accelerating the impact of this financing. We hope the empirical research presented in these studies will contribute to the policy and actual practice of aid management in various contexts, offering insights to donors, governments, the private sector, and civil society.

It has become increasingly clear that the EFA commitment of having every child receive quality primary is achievable, because the means necessary to achieve this goal are essentially known. However, according to a conservative UNESCO estimate, there is a financing gap of around US\$ 7 billion to achieve only a very narrowly-defined range of basic education goals. Equally important is that the aid spent on education should be delivered more effectively. Research on the status of effective aid behaviour in the education sector is still in its infancy. Partner governments' "ownership" of the process, which finds expression in education spending, political commitment and policy innovation, plays a crucial role in aid's effectiveness. Nevertheless, it often tends to be overlooked.

Finally, there are the conditions on the ground, which govern individual access, opportunities and decisions that bring children into school. These include education quality results, learning environments, and disposable family income inter alia.

The financial crisis added an element of urgency to efforts to achieve EFA at the international, national, and local levels. The onset of the financial crisis of 2007-2009, recognized as the most serious economic downturn since the Great Depression, and its reverberations throughout the global economy, put pressures on international aid and

F. Khan $(\bowtie)$

UNESCO Office in New York, 2 United Nations Plaza, New York, NY 10017, USA

e-mail: f.khan@unesco.org

O. Christensen

The World Bank, G8-800, Washington, DC, USA

e-mail: OChristensen@worldbank.org 
partner government budgets. Noteworthy is the strain on poor people's means to send their children to school-instead of to the labour market. The setbacks in economic growth are making it hard for donors to meet their commitments, and, faced with declining revenues and limited financing options, social sector spending is likely to come under pressure as argued, for instance, at the United Nations Conference on the World Financial and Economic Crisis and Its Impact on Development, 24-26 June 2009, New York City.

At the Gleneagles summit of the Group of Eight in 2005 and the UN World Summit later that year, donors pledged, along with other commitments, an increase in aid from $\$ 80$ billion in 2004 to US\$130 billion in 2010 (at constant 2004 prices). Some of these commitments are expressed as percentage of gross national income (GNI). As the global economy contracts, the absolute figures of these commitments decline, reducing the overall commitment target—expressed as percentage of donors' GNI - to US $\$ 121$ billion in 2010, at constant 2004 prices (UN 2009). To compensate for these shortfalls, donors are expected not just to meet their Gleneagles commitments but rather to consider going beyond them. While Denmark, Luxembourg, the Netherlands, Norway, and Sweden are among the countries who met the UN development aid target of $0.7 \%$ of GNI, there are other countries, including Austria, Greece, and Italy, that have met less than half their ODA/GNI targets for 2010 .

Aid to basic education declined by $22 \%$ from 2006 to 2007 (OECD DAC 2007). Addressing these concerns, the Secretary General of the United Nations, Ban Ki-moon, implored world leaders to fill the resource gaps to meet the challenges of the Education for All-Fast Track Initiative (EFA-FTI) and ensure universal access to primary education (Ki-moon 2009). The World Bank estimates that "core" spending on health, education, infrastructure, and social safety nets may drop as much as $\$ 200$ billion as a result of the global decline in economic activity, despite the increases in the number of poor and vulnerable, the reduction in access to education and health services, and the inadequacy of social protection in many countries (Okonjo-Iweala 2009).

Against this historically momentous backdrop, this special issue contributes to the policy dialogue on the promise of aid effectiveness in education, while exploring the lacunae and the constraints we face in these times of financial crisis. This collection of articles shows the evolution of the aid effectiveness movement, clarifies concepts, and addresses contradictions and controversies to propose suggestions for the way forward. This special issue offers insights and presents experiences gained at global and national levels, and includes an analysis of challenges that countries face through two case studies: Cambodia (Asia) and Malawi (Africa). The research findings bear lessons to inform policy and suggest strategies relevant to both donors and recipient countries.

In her Viewpoint, Pauline Rose defines absorptive capacity and introduces the framework to assess the circumstances under which absorptive capacity constraints may impede education and economic development. In the midst of calls for the scaling-up of aid, Rose warns of potential constraints in some recipient countries as they try to absorb substantial increases in resources. In the context of the current economic downturn, questions are raised about of the impact of rapidly increasing external resources on domestic macroeconomic stability. There are two sides to the issue of absorptive capacity. The main issue is, what is the capacity of recipient governments, institutions and agencies to make the most effective use of resources to expand and improve education? Alternatively, what supportive mechanisms enable the recipient countries to utilise the resources provided effectively and efficiently? While absorptive capacity constraints must be dealt with, the author finds it unjustifiable to use them as an excuse for backtracking on the commitments donors made to support countries to achieve the EFA and Millennium Development Goals (MDGs). 
Her Viewpoint concludes by arguing that it is possible - as evidence suggests - to absorb increased resources for expanding and improving the teaching force, for providing funds to schools for teaching and learning resources, and for addressing demand-side constraints. Resources may be more easily absorbed at post-primary levels of the system. However, further research could explore the macroeconomic implications of such increased spending.

The Open File starts with a lead article by Bermingham, Christensen and Mahn, which draws on case studies from several different contexts to argue for improved aid effectiveness in education, as well as the need for reform. Laying out a historical perspective on the evolution of the aid effectiveness debate, the authors draw on their experience with the EFA-FTI to discuss certain inefficiencies inherent in the current aid architecture and process. Their analysis highlights the complexity of translating the Paris Declaration principles into action at the national level. Lack of incentives for staff and management of development partners to change their behaviour, coupled with factors that lead towards risk-aversion and dampen innovations, impede progress in aid effectiveness. Partners need to focus relentlessly on achieving results, which go beyond certain measurable outcomes that are commonly used, such as enrolment figures or test results. These results should capture the raison d'etre of education, which is nurturing confidence and creativity in young people to enable them better to build their countries and have stronger future generations. The authors argue this is why aid effectiveness truly matters.

Sajitha Bashir's article focuses on the contribution of the EFA-FTI global partnership in strengthening the effectiveness of aid in the education sector. The findings are based on a review of the quality of education sector plans of 25 countries and the implementation modalities of the FTI's Catalytic Fund (CF) grants in 18 countries, from 2005 to 2007. In countries with a CF grant under implementation, alignment in the education sector was stronger than for the country as a whole, progress towards harmonization was "somewhat" stronger, while managing for results was equivalent to country level. Areas lagging behind, which need to be tackled, include: the use of country systems for procurement and financial management; coordinated financing mechanisms; joint analytic work; and use of monitoring and evaluation systems that are embedded in the sector monitoring and evaluation strategies. Shortcomings at the global level, where donor agencies predominate, call for improvements in the monitoring of results and accountability. At the country level, recipient governments highlight the need for greater harmonization of reporting, procurement, and financial management.

Laura Collins challenges the efficacy of the twelve indicators designed to monitor the five objectives of the Paris Declaration to adequately measure progress, or even the baseline status, of aid's effectiveness in the education sector. Based on her experience in the Malawi education sector, she argues that the indicators are neither sector nor country specific and she builds a case to examine the underlying assumptions for the proposed framework. She documents for the first time the sector and country specific targets and indicators for the education sector in Malawi. Her analysis suggests that specificity at country and sector level is a prerequisite to maximize the potential of harmonized, aligned, government owned, accountable, and results-managed aid. Her article shows how the government of Malawi is applying the Paris Declaration not only to the national, but also to the sector specific context. The aid effectiveness principles, as formulated in Paris and Accra, are being applied, interpreted, and contextualized. As such, this consultative process and debate have value per se.

Last but not least, Hiroyuki Hattori's article examines the status and progress of Cambodia's education reform. The three priority areas, namely strengthening country ownership, building more effective and inclusive partnership, and delivering and 
accounting for development results, concur with, and endorse, the outcomes of the Accra Agenda for Action. Cambodia has achieved a remarkable development of educational services, despite the civil war in the 1970s, which resulted in the almost complete destruction of the country's education system. Increased momentum for policy-led, programmatic approaches, as well as the creation of formal mechanisms for sector review and annual operational plans - as part of the reform process, helped make significant progress in expanding basic education opportunities. In order to bring about tangible results in educational outcomes through increased aid effectiveness, prerequisites include: a comprehensive sector policy framework, a medium-term strategy on capacity building, and a realistic and reliable finance plan. Hiroyuki's emphasis on decreasing disparities and inequalities in access to education, and the need to improve quality of teaching and learning, are essential lessons to carry forward.

In conclusion, countries today are encountering multi-faceted challenges to assure the effectiveness of aid in education. It is critical to maintain the momentum moving and ensure financing is in place for the MDGs and EFA goals. On the one hand, donor countries need to meet their commitments and provide a larger share of predictable financing for education in developing countries. For example, in order to increase recurrent spending on teacher salaries, developing countries require long-term, predictable financing from donors. However, developing countries need to strengthen their capacities to use these funds effectively through mainstream financing systems to provide equal opportunities to the most poor and vulnerable. Without the aid from stronger countries, developing countries would have no choice but to make forced budget cuts in programmes affecting women, children, education, HIV/AIDS prevention, etc. These are cuts that vulnerable populations cannot afford. Not only will this hinder the achievement of the MDGs; it creates a grave risk that any improvements or progress towards such goals will roll backwards.

Going forward, countries need to adhere to, and in fact step up their aid commitments. The Paris Declaration monitoring report shows that donors have made barely any progress since 2005 on the Aid Effectiveness indicators. Countries require both short-term liquidity and long-term development financing. Short-term mitigation measures should take longterm goals into account, especially those related to poverty eradication, education, sustainable development, food security, gender equality, health, and sustained economic growth. Existing financing systems need to scale up aid to the most vulnerable countries, including those in fragile contexts, to help ensure any progress towards EFA was not made in vain.

\section{References}

Ki-moon, B. (2009). Opening speech. First plenary meeting. United Nations conference on the world financial and economic crisis and its impact on development, 24-26 June 2009. New York City. http://www.un.org/ga/econcrisissummit/statements/sg_opening_en.pdf.

OECD DAC. (2007). Press release. Education for all, global monitoring report team. Organisation for economic co-operation and development/development assistance committee. http://portal.unesco.org/ en/ev.phpURL_ID=42280\&URL_DO=DO_TOPIC\&URL_SECTION=201.html.

Okonjo-Iweala, N. (2009). Individual presentation. United nations conference on the world financial and economic crisis and its impact on development, 24-26 June 2009. New York City.

United Nations. (2009). Millennium development goals report. http://www.un.org/millenniumgoals/pdf/ MDG\%20Report\%202009\%20ENG.pdf. 


\section{Author Biographies}

Faryal Khan (Pakistan) is Programme Specialist for Education at UNESCO's New York Office. She provides technical advice on international education policy to plan for innovative interagency programmes in basic education, including emergency education, and works on issues pertaining to the impact of the global financial crisis on MDGs and EFA. At the UNESCO Division for Educational Strategies and Capacity Strengthening (ED/ESB), UNESCO Paris, she led the UNESCO National Education Support Strategy (UNESS) programme in the Arab States. Her research interests cover fiscal and governance reforms, education in fragile states, and policy and programme evaluation. She earned her PhD in Administration, Planning and Social Policy from Harvard University in 2005.

Olav Rex Christensen (Denmark) is a Senior Public Finance Specialist in the Human Development Network in the World Bank in Washington, DC, working mainly on the Fast Track Initiative (FTI). A Certified Public Accountant, he has a professional background in audit and financial management, both in the private sector and, since 1990, working on development aid. His work has increasingly come to focus on public finance issues and aid effectiveness, more specifically on combining the developmental issues and impact on governance at the country level with donor issues related to fiduciary risks facing the assistance to poor countries with low capacity for implementation and financial management. He has been spearheading FTI's work on modalities and country level processes as well as the FTI Secretariat's work on measuring and promoting aid effectiveness in the education sector. 